\title{
DEVELOPING CIVICS LEARNING DEVICES USING GUIDED INQUIRY TO TRAIN STUDENTS' CRITIKAL THINKING SKILLS
}

\author{
Muhajir \\ muhajir@ymail.com \\ Muhammadiyah University of Makassar
}

\begin{abstract}
This study aimed at producing a valid, practical, and effective Civics learning device with guided inquiry model to train the students' critical thinking skills. The development of learning device used Dick and Carey model and was tested in the classroom using One-Group Pretest-Posttest Design. The data were collected through observation, test, and questionnaire. The data analyses were through descriptive quantitative, qualitative, and t-test.

From the findings in trial classroom, it was found a valid, practical, and effective learning device. It was valid because the average score given by civics learning expert was more than 4 in the interval 1-5, and achievement test showed that it was valid, reliable, and sensitive. It was practical because the teachers' ability in managing the classroom showed good and very good category, and the students activities were categorized as effective. The learning device was effective because the students' response was positive, students' achievement test was thorough, and the students' thinking skill was increased.

Results of the effectiveness of the learning device oriented guided inquiry method can be seen from the teacher's ability to manage learning very well, students' learning activity was effective, students' response was positive, learning mastery was classically achieved namely $93.33 \%$, and students' critical thinking ability increased.

Based on the results of data analysis, it can be concluded that Civics learning device Oriented Guided Inquiry Method developed is feasible and can train students' critical thinking skills in learning.
\end{abstract}

Key words: Civics Learning Device, Guided Inquiry, Critical Thinking Skills

\section{INTRODUCTION}

The 21 st Century is a global century. Social life is changing rapidly due to increasingly integrated world especially supported by advances in information and communication technologies so that the boundaries of society and the state become blurred. The consumers demand high quality of production and continuously improved, so that the professionalism is an absolute requirement in the global life, including teacher professionalism. Professional teachers must have a variety of competency, among others, are able to produce human resources who have the expertise, skills and professions that suit the needs and also suitable with the characteristics and personal aspirations of each student.

Today the problem of education is one aspect of life that gets a lot of attention from the public. Education is not just the media to convey the culture and pass on from generation to generation, but the changes that can develop creativity in the education world. Education is also a strong and authoritative social institution to empower all developed society into qualified humans to be capable and proactive in facing the challenges of the times, which are always changing.

Demand for creating reliable and competitive Human Resources (HR) in this globalization era is a challenge that must be faced by the national education. Efforts to create the human resources can be taken through various aspects of education. However, it cannot be denied that the learning process is the most decisive aspect. Through the quality learning process, it is expected that quality human resources can also be raised. Therefore, effort to improve the quality of learning becomes an absolute thing that must be realized in any learning organization in every level and type of education.

Improving the quality of education through the learning process should be able to fulfill the functions and objectives of national education as stated in article 3 of the 2003 Education Law:

National Education serves to develop the ability and character, and civilization of the nation's dignity in the context of educating the nations is aimed at developing students' potentials to become a man of faith and devoted to God Almighty, noble, healthy, knowledgeable, skilled, creative, independent and become democratic and accountable citizens.

This formulation provides a clear direction for the provision of education in general and the implementation of learning in particular. That any organized learning as an attempt to create human resources that meets the demands of the abovementioned law is a must. Thus, the outputs of education that are reliable, competitive and still have a national character is not merely dreaming but actually can be realized in the life of the nation.

Effort to improve the quality of learning done in the classroom becomes an indicator for the success of the education institution and indirectly it will affect in improving the quality of national education. If the quality of learning that takes place in each class qualified, then it can be ensured that the output generated by the institution concerned is also qualified. Conversely, if the learning that takes place in each class is not qualified, then the expectation of quality output was was only a dreaming. Therefore, in the national education, various studies, trials, training and so on are 
continually developed as an effort to improve the quality of learning. Various approaches, models, strategies, teaching methods and techniques continue to be developed, implemented, and experimented in order to address issues that arise in learning.

Based on the results of research conducted, Soemantri in Soemantri $(2001 ; 289)$ states that in the learning of Civics education, there is a tendency of teachers to use traditional teaching techniques such as; ground covering technique, drill master, indoctrination, and narrative technique. In fact, learning as proposed by Soemantri mentioned above does not occur only in the learning process in schools such as the results of research. Thinking skills of students is very important for their future. Some experts in the field of learning reveal a similar expression, namely in accordance with the opinion of Gedgrave (2009) that the process of gaining knowledge is more important than the product. For a particular Civics learning material, which aims to foster critical thinking skills of students in the classroom, teachers can use the approach to make students more active and use the thinking skills of every learning activities in the classroom. In other words, a learning strategy used is able to seek in order that teacher-centered learning turn out to be studentcentered or student active learning. The role of teachers is only as a facilitator.

Learning device development should be done by teachers before implementing the learning process. The development of learning devices are expected to help teachers to package and present more qualified and varied learning materials.

Along with the development of science and technology, lot of learning materials can be developed to support the achievement of learning objectives as learning innovation. The learning development relies on learning indicators, teaching and learning strategies that will be used, and the subject to be used in order to attract students' interest towards learning. Development of learning tools in which there are strategies or models should increase the ability of thinking.

Critical thinking is correct thinking in the search for relevant and reliable knowledge about the real world (Schafersman, 1991 and Chaffee (in Johnson, 2002, p.187)). The most important thing in teaching critical thinking is to create a spirit of critical thinking, which encourages students to question what they hear and examine their own mind to ensure there is no inconsistent or erroneous logic (Ibrahim and Nur, 2000).

Reality happens in the field until now is that the students' critical thinking skills are not yet taught and are still not measured or tested. From interview with teachers at SMAN 4 Polewali in MGMP event, it is found that if students are given test examples while learning, they were able to accomplish, but if the teacher gives daily tests that contain aspects of critical thinking, students have difficulty in answering the questions. Learning that does not emphasizes on the development of higher level thinking skills (critical thinking skills) tends to put students into memorizing (rote learning). It is very easy for students to forget the material that has been studied before, because the students do not gain experience in developing critical thinking skills. In the view of Slavin (1997), a student must manage his own knowledge by utilizing the brain to think. Learning tools that make students become active can help this process by providing phenomena and questions that exercise critical thinking skills, by learning, designing information to be more meaningful and relevant to the needs of students. It can be done by providing opportunities for students to find or apply their own ideas, and to invite them to be aware and consciously use their reasoning and systematic thinking ability to learn

One of the alternatives that can make students more active in learning activities as well as pay attention to fun atmosphere and closely related to the development of students thinking skills of SMA Neg. 4 Polewali is by using guided Inquiry approach, or Guided Inquiry learning. Guided Inquiry also can help teachers link between the Civics materials with learners real-world situations, and encourage students to make connections between knowledge possessed and the application in their daily lives, both as members of the family and society. Through this concept, the learning outcomes are expected to be more attractive to learners, and can enhance students' thinking skills well.

Noting the objectives contained by Civics Education, learning in school should become favored, challenging, and meaningful activity to learners. Teaching and learning activities implies the interaction of various components, such as teachers, students, teaching materials and other means. To anticipate this, the development of appropriate learning tools should be supported. The use of learning devices oriented to Guided Inquiry is expected to help improve students' critical thinking skills as well as the delivery of messages and content at the time, and also will give a real mastery of concepts realistically.

The development of learning tools is a necessity in natural science subjects that responds positively to the developments of information, science and technology and the demands of decentralization. This is done to increase the relevance of Natural science learning programs with local state and requirements.

By developing learning tools with guided Inquiry-oriented, it can foster better thinking skills so that information obtained through the lesson can cause changes in a positive value on students.

Based on the explanation above, the researchers will develop learning tools oriented Guided Inquiry (including lesson plans, students book, worksheets and Assessment Sheet) to train the students' thinking skills, by submitting the title "Developing Civics Learning Devices using Guided Inquiry to train Students' Critical Thinking Skills".

\section{RESEARCH METHODOLOGY}

This research employed pre-experimental design. Before doing the research, the learning devices that will be used are developed. The research subject was the tenth grade students of SMA Neg. 4 Polewali in odd 
semester academic year 2015/2016 consisting of 30 students.

This research used One Group Pretest-Postest Design (Tuckman, 1978) that can be presented as follows:

$$
\mathrm{O}_{1} \quad \mathrm{X} \quad \mathrm{O}_{2}
$$

Notes:

$\mathrm{O}_{1}=$ Pretest to find out the students mastery on the leraning materials before given learning tools with Guided Inquiry models

$\mathrm{X}=$ treatment by learning tools with Guided Inquiry models using worksheet which is oriented to critical thinking skills

$\mathrm{O}_{2}=$ posttest to find out the learning outcomes and the students mastery on learning materials after given learning tools with Guided Inquiry models

This study consisted of two phases. The preparation phase is the development and the implementation of learning tools in the classroom. Research procedure is using the design of Dick \& Carey learning device development model followed by testing devices in the classroom.

This model starts by identifying general learning goals. Before formulating specific objectives, it needs to analyze the learning and identify students' early behavior. After formulating specific objectives, the next is formulating reference test, that is the test to measure the ability of the specific objectives. To achieve specific objectives, then a learning strategy is developed, that is, the scenario of learning that is expected to achieve the objectives optimally. Then, learning device that is suitable with the objectives are developed. The final step of the design is to perform the evaluation, namely formative and summative evaluation. Formative evaluation is used to assess the program, and summative evaluation serves to determine the position of each student in the mastery of the learning materials. Based on the results of this evaluation is then performed feedback in revising learning programs. Dick and Carey' learning model is stated on the following figure.

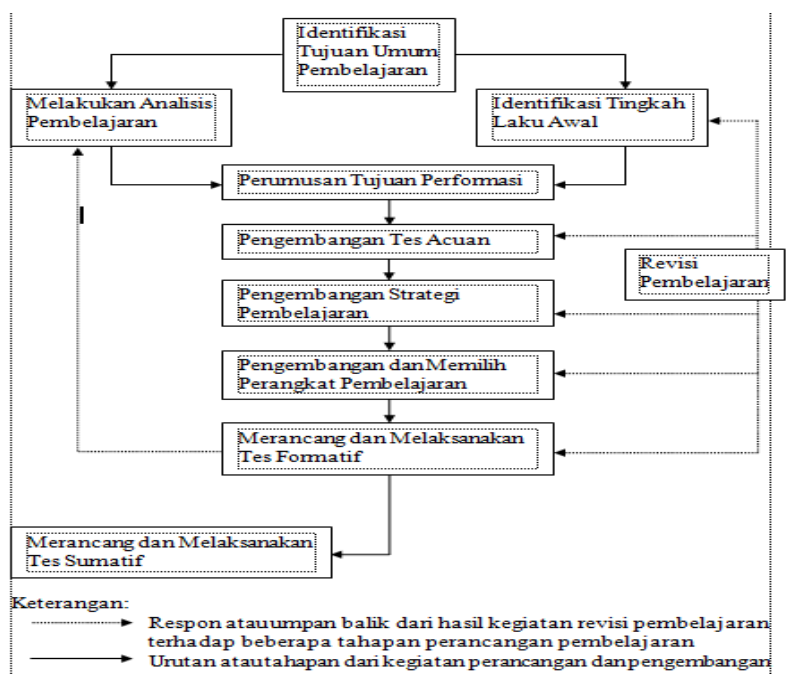

Figure 1. Diagram of Dick and Carey Device

Development model (Dick \& Carey, 1990)

This study uses multiple data collection techniques; they are:

\section{Observation}

Observation is used to obtain research data about the enforceability of the lesson plan, student activities, and barriers when teaching and learning takes place.

\section{Tests}

Test is used to obtain research data on the students' learning outcomes and critical thinking skills. Test is performed as pretest, and after three sessions of learning (posttest). The tests were given for 2-hour lesson (90 minutes).

\section{Questionnaire}

The questionnaire is used to elicit student responses and to determine the students' response toward guided inquiry learning models using students' worksheet oriented critical thinking skills.

The instruments of the research consist of:

\section{Observation Sheet}

a. Observation sheet of the implementation of lesson plan

It is in the form of table with column of observed aspect, implementation, and evaluation. Observed aspect in learning consists of introduction, main activity, closing, classroom atmosphere, and time alocation for each meeting. Implementation consists of two aspescts, yes and no. Evaluation consists of very good, good, fairly good, less good, and not good. It aims at evaluating the quality of lesson plan implementation done by teachers during teaching and learning process.

b. Observation sheet of Students' Activities

It is used to analyze the student engagement in learning process by looking at the percentage of activities undertaken by students during teaching and learning process divided by the overall activities designed, and multiplied by $100 \%$. Students' activities observed are attention, response, hearing teachers/friends' explanation, material reading, worksheet, problem formulation, hypothesis formulation, designing and conducting observation, recording and analyzing the results of observation, presentation, discussion, making inferences, asking the teacher or friend, and behaviors that are not relevant to the teaching and learning process.

Both of observation instruments above were held by two observers, so that the reliability needs to be calculated. Calculation of instrument reliability is done with a technique proposed by Borich (1994), namely interobserver agreement. According to this technique, two observers use the same instrument to observe the same variables, then the observation results are calculated using the formula percentage of agreement as follows:

$$
R=\left[1-\frac{A-B}{A+B}\right] \times 100 \%
$$

Notes: 
$\mathrm{R}=$ Reliability coefficient

$\mathrm{A}=$ Frequency of observed behavior by giving high frequency

$\mathrm{B}=$ Frequency of observed behavior by giving low frequency

Observation instrument is categorized as good if reliability coefficient gained is $\geq 75 \%$.

\section{Students' Learning Outcomes}

a. Achievement test

Achievement test consists of questions addressed to the students in the form of written test. It aims to measure the students' ability in mastering the materials taught and made based on test blueprint based on the learning goals that will be achieved. It is in the form of multiple choice and essay tests. Multiple choice used consists of 5 options, and essay test is used because it can record students thinking process that shows critical thinking skill. Achievement test used should have good sensitivity index. Sensitivity index of an item is the measurement of how well the item distinguishes between the students who have learned and not. Calculating sensitivity of item of multiple choice can be done by using the following formulation (Gronlund, 1982):

$$
\text { Sensitivity }=\frac{\mathrm{Ra}-\mathrm{Rb}}{\mathrm{T}}
$$

Notes:

$\mathrm{Ra}=$ the number of students who answer correctly in posttest

$\mathrm{Rb}=$ the number of students who answer correctly in pretest

$\mathrm{T}=$ the number of students

To find out sensitivity index of essay test, the following formulation is applied:

$$
\text { Sensitivity }=\frac{\sum \mathrm{U} 12-\Sigma \mathrm{U} 21}{\mathrm{~N}(\max \text { score }-\min \text { score })}
$$

Keterangan:

$\Sigma \mathrm{U} 21=$ Sum of pretest score.

$\Sigma \mathrm{U} 12=$ Sum of posttest score.

Max score = Maximal score achieved for every item. Min score $=$ Minimal score achieved for every item $\mathrm{N}=$ number of students

According to Gronlund (1982), item said to be sensitive if the sensitivity of the items was 0.30 up to 1.00. A greater positive value indicates that the sensitivity of items to the effects of learning also getting bigger (Arikunto, 2010). The completeness of student learning outcomes determined from: indicator completeness, individual and classical completeness. An indicator is said to be complete when $\geq 75 \%$ of students achieve the indicator. Minimal completeness criteria of Civics subject at Class X SMAN 4 Polewali are 70 or converted by $>2.80$. Classical learning is said to be complete when $\geq 75 \%$ of individuals are completed.

b. Skill evaluation sheet
It consists of assessed aspects including formulating problems, hypothesis, designing trial procedure, observing, analyzing and concluding data, communicating the findings that concists of concept mastery and presenting. Evaluation of skill competence achievement is done by to the students to assess to what extent the competence achievement particularly in the dimension of skill.

\section{c. Attitude assessment sheet}

It is used to evaluate students' character realized in behavior as the part of learning. Students' character includes spiritual competence (KI-1) associated with the building of faithful students, social attitude (KI-2) consisting of discipline and curiosity. Attitude evaluation comes from observation and self evaluation with checklist and evaluation scale with rubric.

\section{Test of Critical thinking skill}

The instrument consists of questions addressed to the students in the form of written test. It aims at finding out and meazuring students' critical thinking skills in mastering materials taught using worksheet. The instrument is in the form of essay test consisting of 5 questions with the indicators of formulating problems, giving hypothesis, doing analysis, concluding, and evaluating.

\section{Questionnaire}

It is the instrument given to the students in the end of research. The instrument is in the form of table with column consisting of questions and opinion where the options of answers are already determined, the students only need to choose the desired answer. This questionnaire aims at gaining the data about the students' response toward the learning device, learning process, and trained critical thinking skills.

\section{Barriers Observation Sheet}

It is the observation instrument for the barriers happened during learning activity. The instrument is in the form of table with column consisting of the kind of barriers and alternative solution. The aim of this instrument is to find out the barriers risen during learning activity. It is done by two observers while the solution is discussed by observer and researcher. Data analysis techniques in the study was conducted by using descriptive analysis that includes:

\section{Analysis of Device's Validation}

Analysis of the result data of lesson plan validation, teaching materials, students' worksheet, and achievement test result studied by validators to evaluate the eligibility. It is analyzed in descriptive way by averaging the score obtained from the validators. The result is described as follows:

Table 1. Categorizing criteria of lesson plan evaluation

\begin{tabular}{|c|c|}
\hline Interval & Assessment Category \\
\hline $1,0 \leq \mathrm{SV} \leq 1,5$ & Not eligible \\
\hline $1,6<\mathrm{SV} \leq 2,5$ & Less Eligible \\
\hline $2,6<\mathrm{SV} \leq 3,5$ & Eligible \\
\hline $3,6<\mathrm{SV} \leq 4,0$ & Very eligible \\
\hline
\end{tabular}

(Adapted from Ratumanan \& Laurens, 2011) 
Reliability of the instrument is determined based on validators' assessment. The level of reliability is calculated by using the following formulation:

$$
\mathrm{R}=\frac{A}{D+A} \times 100 \%
$$

Notes:

$$
\begin{aligned}
& \mathrm{A}=\text { Agreement between evaluator } \\
& \mathrm{D}=\text { Disagreement between evaluator } \\
& \mathrm{R}=\text { Reliability of the Instrument }
\end{aligned}
$$

According to Borich (in Ibrahim, 2005) instrument is said to be reliable if the reliability gained is $\geq 0.75$ or $75 \%$.

\section{Analysis of the result of device's implementation}

a. Implementation of Lesson Plan

The implementation of learning steps is observed by two trained observers so that they can operate observation sheet correctly on the instrument criteria for each phase of learning assessed by providing checklist in implementation column (yes or no) and on assessment columns (5: Very Good, 4: good, 3: Fair, 2: Less good, 1: Not good).

The observation results were analyzed through descriptive quantitative by comparing the average of rating scale given by the two observers with the

\begin{tabular}{|l|l|l|l|l|l|}
\hline \multirow{2}{*}{ No } & $\begin{array}{l}\text { Students } \\
\text { activity }\end{array}$ & \multicolumn{3}{|c|}{ Meeting (\%) } & Avera \\
\cline { 2 - 5 } 1 & $\begin{array}{l}\text { Pay (\%) } \\
\text { attention to } \\
\text { the teacher }\end{array}$ & 14.4 & 15.4 & 13.7 & 14.2 \\
\hline 2 & $\begin{array}{l}\text { Cooperate in } \\
\text { group }\end{array}$ & 23.1 & 22.0 & 23.2 & 22.7 \\
\hline 3 & $\begin{array}{l}\text { Discuss with } \\
\text { the group } \\
\text { members } \\
\text { through } \\
\text { guided } \\
\text { inquiry }\end{array}$ & 22.0 & 25.0 & 24.9 & 24.3 \\
\hline 4 & $\begin{array}{l}\text { Answer the } \\
\text { questions in } \\
\text { wroksheet }\end{array}$ & 9.7 & 9.5 & 9.3 & 10.2 \\
\hline 5 & $\begin{array}{l}\text { Presenting } \\
\text { the result of } \\
\text { activity }\end{array}$ & 6.8 & 5.7 & 4.9 & 5.8 \\
\hline 6 & $\begin{array}{l}\text { Ask, answer, } \\
\text { and respond } \\
\text { the question }\end{array}$ & 18.2 & 16.3 & 16.4 & 17.0 \\
\hline 7 & $\begin{array}{l}\text { Irrelevant } \\
\text { behavior }\end{array}$ & 1.9 & 0 & 1.7 & 1.2 \\
\hline 8 & $\begin{array}{l}\text { Conclude } \\
\text { the result of } \\
\text { discussion }\end{array}$ & 0.9 & 4.8 & 6.8 & 4.2 \\
\hline
\end{tabular}

following assessment criteria:

$$
\begin{array}{lll}
1,00 \leq X \leq 1,49 & : & \text { Not good } \\
1,50 \leq X \leq 2,49 & : & \text { Less good }
\end{array}
$$

$$
\begin{array}{lll}
2,50 \leq X \leq 3,49 & : & \text { Fairly good } \\
3,00 \leq X \leq 4,49 & : & \text { Good } \\
4,50 \leq X \leq 5,00 & : & \text { Very good }
\end{array}
$$

\section{FINDINGS AND DISCUSSION}

\section{A. The quality of learning device}

The validation of learning device developed in this research is carried out by two validators and supervisors who show that: 1) guided inquiry as the result of development is categorized as eligible; 2) developed lesson plan is categorized as eligible and very eligible; 3) developed worksheet is categorized as eligible for every aspect; 4) developed achievement test is categorized as eligible for every assessment criteria; 5) developed test of critical thinking skill is categorized as eligible.

\begin{tabular}{|c|c|c|c|c|c|c|c|c|c|c|c|c|c|}
\hline \multirow{3}{*}{ No } & \multirow{3}{*}{$\begin{array}{c}\text { Aspek yang } \\
\text { Diamati }\end{array}$} & \multicolumn{12}{|c|}{ Pertemuan } \\
\hline & & \multicolumn{4}{|c|}{1} & \multicolumn{4}{|c|}{2} & \multicolumn{4}{|c|}{3} \\
\hline & & $\mathrm{P} 1$ & P2 & $\begin{array}{c}\mathrm{Re} \\
\text { rata }\end{array}$ & Ket & P1 & $\mathrm{P} 2$ & $\begin{array}{l}\mathrm{Re} \\
\text { rata }\end{array}$ & Ket & $\mathrm{P} 1$ & $\mathrm{P} 2$ & \begin{tabular}{|c|} 
Re \\
Rata
\end{tabular} & Ket \\
\hline 1 & Pendahuluan & 2,7 & 2,9 & 2,8 & $B$ & 3 & 3 & 3 & $B$ & 3 & 3 & 3 & B \\
\hline 2 & Kegiatan inti & 3 & 3 & 3 & $B$ & 3,1 & 3 & 3,0 & B & 3,2 & 3,1 & 3,1 & B \\
\hline 3 & Penutup & 3 & 3 & 3 & B & 3 & 3 & 3 & B & 3 & 3 & 3 & B \\
\hline 4 & Suasana kelas & 2,7 & 3,1 & 2,9 & B & 3 & 3 & 3 & B & 3,2 & 3 & 3,1 & $B$ \\
\hline & Jumlah & 11,4 & 12,0 & 11,7 & & 12,1 & 12,0 & 12,0 & & $\begin{array}{c}12 \\
4\end{array}$ & $\begin{array}{c}12 \\
1\end{array}$ & 12,2 & \\
\hline & Reliabilitas & & 81,750 & & & & 85,09 & & & & 89.180 & & \\
\hline
\end{tabular}

\section{B. The result of trial II of learning devices}

The findings includes process and result of learning including implementation of lesson plan through guided inquiry, students' activity, students' response, and test of students' critical thinking skill.

\section{The implementation of lesson plan}

The result of lesson plan implementation can be seen in Table .

The implementation of lesson plan through guided inquiry is good with the average reliability from 2 observer was $80.3 \%$. it shows that teachers' activity in teaching is suitable with the steps of guided inquiry model. This good implementation of lesson plan is supported by positive response that $83.6 \%$ students are interested in joining teaching learning process for other topics, and $83.3 \%$ students are interested with new teaching method, worksheet, and classroom atmosphere.

2. Observation result on the students' activity in Teaching Learning process

Students' activity is any activity carried out by students during the teaching learning process. The students' activities can be seen in Table 2 .

\section{Students' response to learning process}


Learning devices in this research are responded positively by the students as presented in Table 3 .

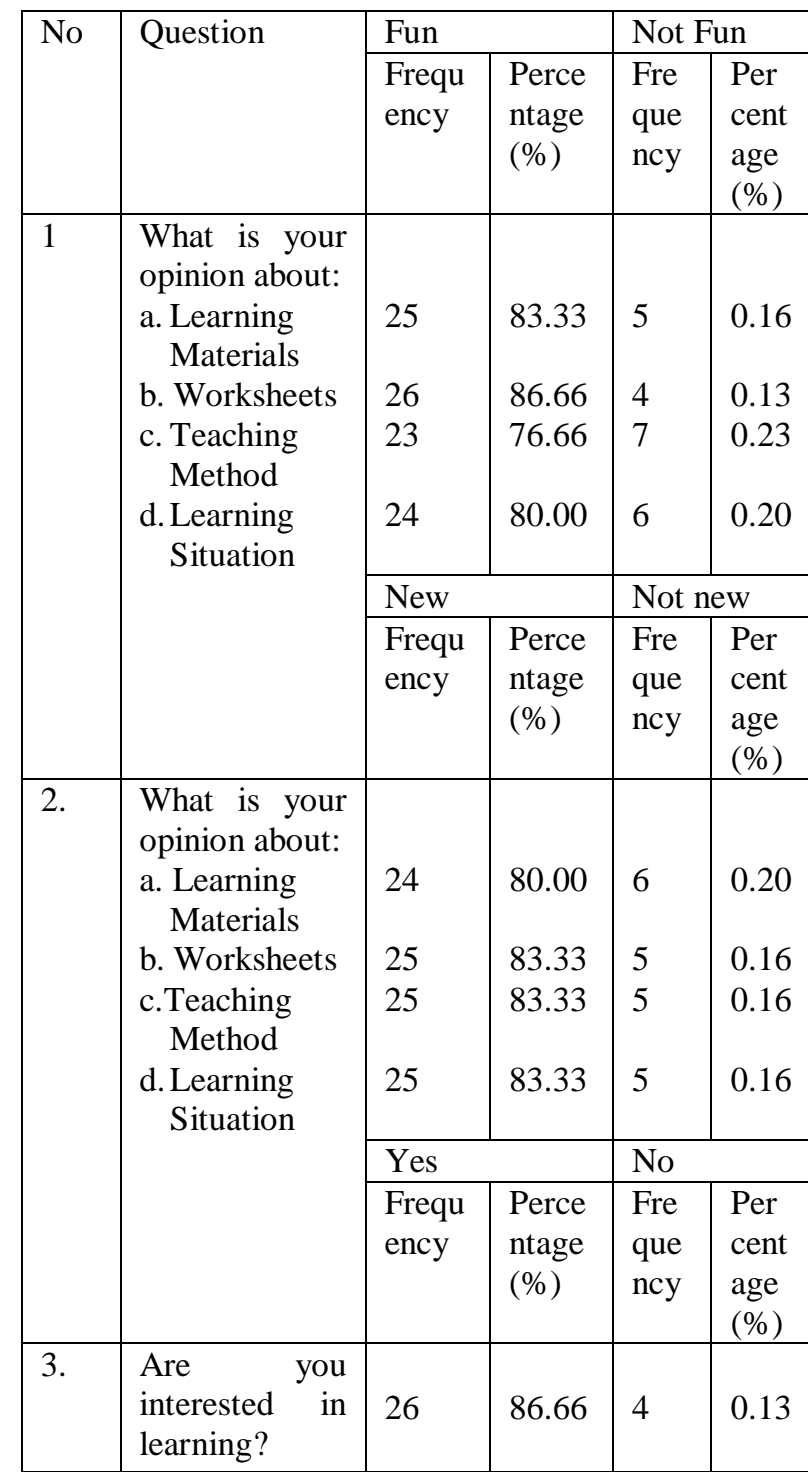

Table 3 shows that the students' response to the components of the Civics learning activities guided inquiry-oriented collected through questionnaires is very good, and it can be stated that most of the students are interested in learning civics through guided inquiry because it is a new, good, fun and exciting learning.

This is supported by observation of the implementation of lesson plan that shows assessment value of core activities, which has average 3 , and is categorized as good. $86.6 \%$ of students are interested in participating in learning activities for topics of other materials to train students' critical thinking skills. This is supported by students' learning outcome which is $100 \%$ thorough.

Based on the above data analysis, it was concluded that the students responded positively and well to the learning using worksheets to improve students' critical thinking skills. Good response indicates the motivation of students towards learning is also good. Motivation of students is supported by the theories of motivation from Westwood (2004) that the implication of learning is to give awards to motivate students. It is reinforced by Daryanto (1993) which states that one of the roles and advantages of learning media is to generate motivation. If students are interested in learning, the information obtained from the senses will be more easily distributed to the brain and is not easily forgotten by long-term memory because it has meaning.

\section{Students' Critical Thinking Skills}

The test result of the students' critical thinking skills in Table 3 above shows that four of the tested indicators of critical thinking has quite good sensitivity, ie answering the question why 0.41 , giving reason 0.54 , making conclusion of 0.59 , and formulating alternative to solve the problem 0.41 . Thus, the critical thinking skills test instrument has good sensitivity and fit for use. The calculation of Gain-Score of the critical thinking ability test

\begin{tabular}{|c|c|c|}
\hline Students & Gain (g) & Notes \\
\hline 1 & 0.29 & g-medium \\
\hline 2 & 0.66 & g-medium \\
\hline 3 & 0.65 & g-medium \\
\hline 4 & 0.90 & g-high \\
\hline 5 & 0.85 & g-high \\
\hline 6 & 0.48 & g-medium \\
\hline 7 & 0.96 & g-high \\
\hline 8 & 0.89 & g-high \\
\hline 9 & 0.65 & g-medium \\
\hline 10 & 0.82 & g-high \\
\hline 11 & 0.63 & g-medium \\
\hline 12 & 0.77 & g-high \\
\hline 13 & 0.69 & g-medium \\
\hline 14 & 0.64 & g-medium \\
\hline 15 & 0.75 & g-high \\
\hline 16 & 0.64 & g-medium \\
\hline 17 & 0.88 & g-high \\
\hline 18 & 0.84 & g-high \\
\hline 19 & 0.53 & g-medium \\
\hline 20 & 0.63 & g-medium \\
\hline 21 & 0.79 & g-medium \\
\hline 22 & 0.69 & g-medium \\
\hline 23 & 0.72 & g-high \\
\hline 24 & 0.68 & g-medium \\
\hline 25 & 0.68 & g-medium \\
\hline 26 & 0.76 & g-high \\
\hline 27 & 0.66 & g-medium \\
\hline 28 & 0.95 & g-high \\
\hline 29 & 0.78 & g-high \\
\hline 30 & 0.99 & g-high \\
\hline $\begin{array}{l}\text { gain- } \\
\text { score }\end{array}$ & 0.73 & g-high \\
\hline
\end{tabular}

The data shows that the Civics learning process through guided inquiri can improve students' critical thinking skills. This is consistent with Piaget's theory, that the child may think a high level when he has enough concrete experience and guidance to enable the 
development of concepts and relationships of necessary facts (Nur, 2008).

This is supported by Buris and Garton (2007) that it takes 10 to 16 weeks to familiarize students in improving their critical thinking skills. Meanwhile, according to Vygotsky, learning through guidance occurs through interaction with the teacher or the students who are more capable to make the thought process is open to all students, both from themselves and from other students. In the model of cooperative learning students are exposed to the thought process of their peers (Nur, 2008).

\section{CONCLUSION}

From the data analysis and discussion, it can be concluded that the Civics learning device by using the guided Inquiry in class X SMA Neg. 4 Polewali produced is effective to be used in learning in terms of enforceability of the learning devices, student activities, Student worksheet, Instrument Evaluation, and students 'responses. Most of the students gave a positive response so that the learning device is effective to improve students' learning outcomes and critical thinking skills.

Based on these findings, it is concluded that the application of Guided Inquiry in the development of Civics learning tools to train thinking skills of students is valid, practical and effective to use in learning.

\section{REFERENCES}

Arikunto, S. (2010). Management Research. Jakarta: Rineka Cipta

Borich, G. D. (1994). Observation Skill for Effective Teaching. New York: Macmilan publishing Company.

Depdikbud. (2013). Permendikbud No. 66 of 2013 About Standard Assessment of Primary and Secondary Education. Jakarta: Depdikbud

Depdikbud. (2013). Permendikbud No. 81A Appendix IV of 2013 On Implementation of the General Education Curriculum Guidelines.Jakarta: Depdikbud

Dick, W and Carey, L. (1990). The Systematic of Instructional Design $3^{\text {rd }}$ Edition. Melbourne: Merril Publishing Company.

Duron, R. (2006). "Critical Thinking Framework for Any Discipline". International Journal of Teaching and Learning in Higher Education. Vol.17 No.2, pp 160-166

Fisher A. (2009). Critical Thinking: An Introduction. Jakarta: Erlangga

Hake, Richard R. (1999). Analyzing Change/Gain Score. Dept. Of Physics, Indiana University 24245 Hatteras Street, Woodland Hills, CA, 91367 USA.
Ibrahim, M. (2005). Sustainable Assessment. Surabaya: Unesa University Press.

Kardi, S. (2013). Direct Inquiry Learning Model Science Technology and Society. Surabaya: Surabaya State University

Kasnan, N. (2001). "Skills Improvement Process Through Cooperative Learning Method with Group Assignment, Presentation and Exhibition in Subjects Biology. "Journal of Educational Genteng Kali (East Java Education Bulletin). Volume 3 No. 8 things 10-11.

Khabibah, S. (2006). "Development of Mathematics Instructional Model to Enhance Creativity Problem Open for Elementary School Students". (Dissertation is not published). Graduate of State University of Surabaya.

Marzano, Robert J (1992). A different Kind of Classroom: Teaching Science for All Children. Massachusetts. Allyn and Bacon.

Mulyasa, E. (2013). Development and implementation of Curriculum 2013. Bandung: PT. Remaja Rosdakarya.

Nur, M. (1995)." Problem-based Learning Model Development Oriented Civics PKP to improve the Power of Reason in order Toward Student Science Society on Long-Term Development Second Phase" Competitive Grants Article II / 2 College of Fiscal Year 1994/1995.

Nur, M. (1998). Cognitive Learning Theory. Surabaya: Unesa University Press.

Nur, M. (2008). Problem Based Learning Model. Surabaya: Unesa University Press.

Putra Rizema, S. (2013). Creative Teaching and Learning Design-Based Science. Jogjakarta: DIVA Press

Ratumanan, G. T. (2004). Teaching and Learning Volume 2. Surabaya: Unesa University Press.

Ratumanan, G. T, Laurens T. (2011). Learning Outcomes Assessment in Education Unit Vol 2. Surabaya: Unesa University Press.

Sanjaya, Wina, (2009). Standard Process Oriented Learning Strategy Education. Volume 6. Jakarta: Kencana Perdana Media Group.

Savinainen, A. and Scott. P. 2002.” The Force Concept Inventory: A Tool for Monitoring Student Learning". Physic Education Journal. Vol. 37 No.1, pp: $45-52$

Slavin, R. E. (1994). Educational Psycology: Theory and Practice. Fort Edition. Boston: Allyn and Bacon Publishers. 
Slavin, R. E. (2011a). Theory and Practice of Educational Psychology ninth edition, Volume 1. Jakarta: PT. Indeks.

Slavin, R. E. (2011b). Theory and Practice of Educational Psychology ninth edition, Volume 2. Jakarta: PT. Indeks

Trianto. (2007). Innovative Learning Model Constructivistic Oriented. Jakarta: Prestasi Pustaka.

Trianto. (2009). Designing Innovative Learning Progressive Model. Jakarta: Kenaba Perdana Media Group

Tuckman, B. E. (1978). Conducting Educational Research. New York: Harcourt Brace Jovanavich Publisher.

Watkins, Marley W \& Pacheco, Miriam. (2001). "Interobserver Agreement in Behavioral Research: Importance and Calculation." Journal of Behavioral Education. Vol 10 No.4.pp 205-212. 